\title{
Does Literature belongs to the Biosphere? The Italian Case of Luigi Meneghello
}

\author{
Diego Salvadori \\ University of Florence, LILSI, Italy
}

*Corresponding Author: Diego Salvadori, University of Florence, LILSI, Italy

\begin{abstract}
This study investigates the relationship between text and biosphere in the works of the Italian writer Luigi Meneghello (1922-2007), framing it within the context of his overall literary production. Starting from this analysis, the author's ecological view stands up in a triple aspect: the 'text' as 'ecosystem', characterized by an organicistic view of the writing process; the ecological crisis and pollution, resulting in a development of environmental ethic; ecology of things, according to the perspective of the Material Ecocriticism. The essay also looks at the animals presences in Meneghello's works, raising the possibility of a criticism of anthropocentric view.
\end{abstract}

Keywords: Comparative Literature, Ecocriticism, Ecology, Italian Literature, Linguistics, Luigi Meneghello

\section{INTRODUCTION}

In his Six Memos for the Next Millennium, published in 1988, Italo Calvino wrote that "fantasy is a place where it rains" (1993 109), in reference to a line of Dante's Purgatorio "Poi piovve dentro a l'alta fantasia" (XVII, 25: "Then rained down into the high fantasy"). And, in order to introduce an ecocritical analysis of Luigi Meneghello's literary production, we could move this observation from a visionary to a strictly textual field: if ecocriticism investigates the link between literature and environment, taking an earth-centered perspective, in Luigi Meneghello's writing the nature element appears from his first book, Libera nos a malo, published in 1963. The title of the book refers not only to the Latin version of the last line of the Lord's Prayer, but also to Malo, a small town near Vicenza, where he was born and lived until 1947, when he left Italy to go to England (a few years later, he founded a highly influential Italian Studies department at the University of Reading, which he directed until his retirement in 1980). This is the first line of Libera nos a malo (We quote from the english translation, under the title Deliver Us): "In the beginning there was a thunderstorm" (Meneghello 2011: 3). This shows how the relationship between text and biosphere is obvious and clear from the start, giving rise to a narrative fluid which pervades all his works. There is a secret capillarity in Meneghello's writing. As he himself said: "all of my books are connected, like

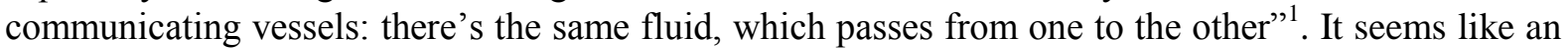
underground river, a primordial soup whose textual vitality is constantly nourished by experience. However, if the meteorological phenomenon (the thunderstorm of the first book) becomes source, the author's relationship with Nature is delineated in other works, forming concentric circles, a perfectly balanced system. We can consider, for example, Trapianti [Transplants], published in 2004, where Meneghello translates, in the dialect of Vicenza, authors like Shakespeare, Yeats, Hopkins, etc., and where the title is related to the botanical field (transplants like bedding plants); or we can refer to Quaggiù nella biosfera [Down Here in the Biosphere], essays on the aesthetic qualities of literary works (qualities which Meneghello defines as "poetic yeast"). This last point is one of the most important, recalling the observations put forward by Joseph Meeker in The Comedy of Survival: "literature", Meeker stressed, is "an important characteristic of the human species" (Meeker 1972:3); and we can apply this concept to the title of Meneghello's book, because the biosphere is the domain of literature, its poetic yeast.

\footnotetext{
${ }^{1}$ Meneghello 2005 (1997): 65. Original line: "Tutti i libri che ho pubblicato sono collegati tra loro, come vasi intercomunicanti: c'è dentro lo stesso fluido che passa dall'uno all'altro".
} 


\section{OBJECTIVES}

With this in mind, Meneghello's books recreate a deep connection between the components of the Earth: a textual ecosystem. The result is a proper biodiversity, expressed by the author in his prose, as demonstrated by the linguistic interactions between Italian, English and the dialect of Vicenza. This suggests a constant exchange between the bios (the life), the logos (word and narration) and the semèion (the linguistic sign): what we have here is a true semiotic continuum, a semiosphere (a sphere of semiosis in which sign processes operate in the set of all interconnected Umwelten). As Jurij Lotman stated: "all semiotic space may be regarded as a unified mechanism (if not organism)" (Lotman 2005: 208). The links between these three sides occur at several points of the first book:

Experience in Malo is reflected upon and processed through the spoken word and mimicry, and thus by its nature is fleeting and written on air, but that does not mean it is crude. The genre is almost universally that of laughter - life as comic theater - but expressed so effectively, with such pliancy and richness, that it could make many similar sides of contemporany literature seem dull and labored. (Meneghello 2011: 299)

The passage quoted clarifies the link between nature and language: a continuity mediated by the physical element (the air), which becomes narrative agency and leads to a sequence of constant interaction between man and the nature. We have remnants from pre-Socratic philosophy (air as pnèuma, the breath of life), but the preeminence is accorded to the linguistic entity, funnelled through the organic and natural domain, in a retroactive relationship between text and world. In Malo - the textual setting of Meneghello's first book - there is a somatic sociality and, for this reason, the place is the oikos:

The town of the past had its qualities: it shaped a human community that was modest but organic. We all knew everyone, relations between the young and the old were more natural, relations between human beings and thing were stable, ordered, lasting. Houses, public works, furniture, the objects of daily life: all lasted a long time. Everything was encrusted with experiences ad memories thickly laid one over the other. [...]

You were inside a tight net of genealogies [...]. (Meneghello 2011: 127-128)

The place is vital, pulsing, relating to a porosity of existences: a membrane which links living beings and materials, according to Barry Commoner's first law of ecology: "everything is connected to everything else" (Commoner 1972: 16). Meneghello - and this applies to all his works - writes a collective autobiography - in flux, because it is enriched in book after book - which is an autobiography of three particular subjects: the author, the people of Malo and Malo itself. For example, in a work published in 1986, and entitled L'acqua di Malo [Malo's Water] (water again, some would say), he describes the physical structure of the place and particularly the ancient waterworks (as a vital underground network, with which people have an osmotic relationship). For this reason, the autobiographical self is not solipsistic, but passes through a process of self-awareness, made up of intellectual fluxes: the monadic Self is disintegrated, but gathers itself up again in a shared biosphere.

But Malo is also the starting point of Meneghello's environmental awareness: the town is described during the process of its transition from a rural society to an industrialized one (the book was published in 1963, at the height of the Italian Economic Miracle). For this reason, the author focuses on its interconnected structure, what Malo had been in the past: a network of counter-balanced forces altered by industrialization:

Town was structure genuinely built to the measure of man, literally to the measure of our fellow townsfolk, and therefore is fitted the natural scale of our lives. What was there had mostly been made there, while today things descend from on high, factories plummet down from the heavens of a greater economy, bringing new shapes to thing, on the one hand civilizing us, on the other, dehumanizing us. (Meneghello 2011: 136).

Meneghello emphasizes the deep connection between text, social context and physical space. The text now becomes an extension of place (an extension of Malo); a place which is narrated and described through a temporal border: past and present clash, endangering Malo's identity. As the author states at the end of the passage quoted, this "new shapes to thing, on the one hand civilizing us, on the other, 
dehumanizing us" (ibidem): in light of this, Malo becomes a palimpsest erased and deprived of its traditions. The environmental point of view can be found in the awareness of change: the disappearance of a world and its transformation into a fossil, a residual system (as is the case in Pomo pero, Meneghello's third book, published in 1974, where Malo has become a ghost town). But, returning to the passage quoted, we can infer the mixed nature of the chronotope: we have a dual temporal basis - as demonstrated by the passage from past to present tense ("Town was structure [...] while today things descend [...]") - but a dual spatial level too - high and low, inner and outer. The book is about a dying place, as we read in the following extract:

All forms of life die, and so it is natural (if hard to believe) that it also happens in Malo. There's no escaping the fact that something new is being born here; at first it seems merely inane, freakish, and the we see that it occupies the streets, the taverns, and the houses, it has become the foundation of the town - and the freak is us [...].

New things arrive and become second nature in the interval between one year and the next. (Meneghello 2011: 326-327)

This shows a constant interaction from two sides - life and linguistic systems: the environment incorporates these new structures and makes them narrative. This is why - according to an ecocritical analysis - the text is not separated from the world, but becomes a complex system, extended to include the entire biosphere. It is why we can read Meneghello's writings from the perspective of Material Ecocriticism theories, in light of a background materialism and the subsequent overcoming of the ontological hiatus between Res Cogitans and Res Extensa. It goes without saying that the material world is no longer opposed and separated from man, but - since it has become readable and open to interpretation - linked to the biosphere's dynamism, giving rise, in the text, to an intertwined flux of matter and discursive forms. Moving on to what we said earlier, and especially to Malo's human-induced changes, we can see how matter becomes narrative, telling the story of the transformation of the original place:

In this place that is both modernizing and falling to pieces, I said to myself, things from the past will come to have more meaning, not less. Chromes drives out wood; fake marble, stone; neon, the old light bulbs; bathrooms enter the houses; modern cookers replace the old stoves; radiator, refrigerators, and carpets are coming. (Meneghello 2011 [1963]: 117)

Materials have their own expressiveness, overlapping with previous buildings: things have semiotic value, they are creative and creators. As Hubert Zapf stresses: "creativity is a feature not only of cultural evolution or of the biotic sphere of living nature, but of the world of the nonliving matter itself" (Zapf 2014: 52). An intermediate zone is emerging, where abiota at once cooperates and acts in the text and as text: in the diegesis, the author overcomes the solipsism - which is typical of the autobiography - by adopting a point of view which is at once static and dynamic. A materialistic vision of life can also be deduced from Meneghello's idea of language and, especially, the constant interaction of dialect and Italian:

A man's personality is made of two strata: on top, lie the superficial wounds in Italian, French, Latin, or whatever; down below, the older wounds that, healing, made scars of the words in the dialect. Touch one and it sets off a chain reaction, very difficult to explain to someone who has no dialect. (Meneghello 2011: 46)

This view of a corporeal language goes with the idea of a 'solid word', meant to fit into a semiotic network (which is why the literary text is not separated from the world). As Meneghello states:

The dialect word is eternally pegged to reality because the word is the thing itself, perceived even before we begin to reason and its power doesn't diminish with the time [...].

But this core of primordial material $[\ldots]$ also contains uncontrollable forces precisely because it belongs to a prelogical sphere, where associations are free and fundamentally manic. (Ibidem)

Language and the material world are deeply connected, linked to the "DNA of reality" - as Meneghello wrote in one of his works: a system of "patterne" (Meneghello 2000 [1999]: 500), which is an Italianized form of the English "pattern" (and this leads to an idea of an entangled, solid reality). Then, on one side, we have a physiological language, a skin-language, which is natural, organic, deeply connected to the natural cycles and reactions; on the other side, we see how writing is 
encrusted with meanings and experiences. Meneghello breaks up the Cartesian dualism between Mind and Body and, in some ways, considers the latter as a point of exchange and constant contamination. According to this view, the physical book becomes not only the place for a mimetic reproduction of natural phenomena, but the starting point to recreate a possible world, a second nature. He will write in an extract from the first volume of Le Carte [The Papers], published in 1999, which we've tried to translate:

In a book, I would recreate the anarchist freedom of this snow mixed to the rain of march, making it a meaning sequence. All this movement in the space up ahead, all this fuss. Something brisk, something dense falls out from the sky and then it fades away, touching the earth and the roof; everything is wet, everything is happy.... I would make a thing that happens, an event and the scene of the event where this alive stuff crashes. It take the discipline of reasons, of meaning.

Then, it snows, everything has gone into action, spinning [...]. It's not a drift of numbs, it's the universe snows. ${ }^{2}$

If the writing aims at something unique, inaccessible with normal cognitive tools, the natural world which is free, anarchic; but self-organized at the same time - becomes the test bench for this operation, by which Meneghello tries to make the natural phenomena readable. But, as we said, it is not a mimetic reproduction, but rather a weighing between reason and significant: a recreation that, when it describes the world, raises the text into a connection with the biosphere.

With this first analysis we were able to find, on the one hand, what might be called Meneghello's 'ecology of words', which frames a proper textual ecosystem (because the thunderstorm, from the first line of his first novel, is the source of an underground river, a system of communicating vessels); on the other hand, we have been able to observe how the human subject and the writing are deeply connected to the biosphere (through which the text is an ecosystem).

Now let us examine Luigi Meneghello second book, I piccoli maestri, published in 1964 and translated into English as The Outlaws in 1967. In this work, Meneghello talks about his experience as a partisan in the Italian Resistance, and the book - in an ecocritical reading of Meneghello's works plays a crucial role, because part of it takes place in the mountains and, in particular, in the Altipiano d'Asiago, a mountainous area near Vicenza. In this case, the place is both the center of the action and the element that generates the narrative itself (he began writing the book on his return to Asiago in 1963). And the following extract could be considered a perfect example of nature-writing, along the lines of Henry David Thoreau or Ralph Waldo Emerson:

I understood that there was something important for me to see, but I didn't know where to look. Then I saw that, a couple of yards away from us, there was a young hare. He must have come out of a bush; he was sitting there, looking at the view.

It was a wonderful moment, the shadows were limpid and fresh, the leaves hanging from the branches were like luminous membranes. (Meneghello 1967: 103)

The animal creates a displacement of perspective, inducing the human being to rethink his place in the world: living in the wilderness, in fact, not being resolved in a simple contemplation, but rather originating a new ethic, an original approach to the reality, life and the biosphere, because "the world is a mysterious place, and one feels this much more when one has lived a good while in the wilderness" (Meneghello 1967: 107). This is shown also by the following extract:

When the cuckoo called - because in the Altipiano they call in May - we were not there as spectators, tourists, who listened just for our own pleasure and then went back to hotel diningrooms, to telephones, to ordinary things of life. We lived there in the woods, with these cuckoos, they were real things to us and not just wonders of nature. (Ibidem)

\footnotetext{
${ }^{2}$ Meneghello 2000 [1999]: 60. Original line: "Vorrei nel libro la libertà anarchica di questa neve mista con la pioggia di marzo. Farne una sequenza significante. Tutto questo movimento nello spazio qua davanti, questo trambusto. Qualcosa di vispo, di fitto, casca dal cielo e poi toccando la terra e i tetti svanisce; tutto è umido, allegro... Farne una cosa che accade, un evento e insieme la scena dell'evento sulla quale questa roba viva precipita. Ci vuole la disciplina della ragione, del significato. Poi nevica fitto, ogni cosa si è messa in moto, turbina $[. .$.$] . Non è un cumulo di nubi, è l'universo che nevica".$
} 


\section{CONCLUSIONS}

As we said, animals have a central role in this book: they close the gap between man and animal, laying the groundwork for a non-anthropocentric perspective. We are faced here with a holistic perception of nature, which follows from the practice of reinhabitation(Snyder 1987: 28). The human subject, now, not only sees but above all feels the environment: a circle that surrounds the body and the mind. We are far from an aesthetic appreciation of nature: the ontological borders fade out, and this leads to a blurring of boundaries between the human and the animal world. The forest is now a meditative space, where man can once again discover his relationship with nature:

Once I stood alone on a boulder in the woods and began to day-dream, because in the woods inevitably one ends up by day-dreaming - perhaps this happens whenever one is alone: shapeless thoughts roll up slowly and continuously, they mean nothing, yet seem to carry the sting of truth. This must be why we praise solitude. (Meneghello 1967:108)

Like Thoreau's Walden, but also like Arne Naess and his Ecosophy T., isolation from society leads to a re-enchanted view of nature:

So, as I stood day-dreaming on this boulder I asked myself what a wood is. There are times, I thought in a kind of free-wheeling way, when things are seen more clearly out of the corner of the eye, of five thousand eyes, of fifty thousand or even more. That's was perception is. These eyes, my mind ran on, most likely are one above the other, overlapping, the total superimposition one can call-what? - a wood maybe - that seems a good enough summaryone can all call it man, this branch of homo that we are, that has come out of the woodultimately the human brain and the wood are the same thing - and in society we have reproduced the wood and the brain, and all that is in them must also be in society. (Ibidem)

The mountain and the wood are a true phonosphere: the human subject harks to the sounds of the Earth (the voices of animals), entering a state of simultaneity with the environment. This is a rediscovery of Nature, by which human being transcends his sensory faculties, irreparably confined to a tight perimeter, and perceives the entire world, beyond his or her physical and mental borders; moreover, in overcoming the ontological hiatus, Meneghello compares two different anatomies human and animal -and traces their common roots. We can assume the presence of an immanent mind, clinging closely to the outside (i.e. nature and the environment). As Merleau-Ponty stressed, to look at an object and live it are the same thing, and the perception - which Meneghello analyzes in the quoted extract - allows the human subject - who has found his place into the Nature - to achieve a new idea of the environment, brought on by a perfect osmosis between mental and physical space. An overlapping phenomenon is taking place, and this is why the body - as Merleau-Ponty asserted in L'eeil et l'esprit - "is a thing among things, is one of them [...]. Things are annexations or prolongations of the self; they are incrusted in its flesh; they are parts of its full definition; the world is made of the very stuff of the body" (Johnson 1993: 125). In Meneghello's book, the wood and the mind are the terms of a perfect equivalence, and this why we can consider Gregory Bateson's concept of 'creatura', expounded in his Steps to an Ecology of Mind. If the creatura is "the world sees as mind" (Bateson 1972: 464), Meneghello can feel what's the wood is, because the mind - quoting Bateson again - arises as "immanent in the large biological system - the eco system" (Bateson 1972: 467). In the mountains, therefore, the subject develops a new ethic, he approaches Nature by rediscovering the union of body and mind within a greater whole: ideas extend outward and return to the subject with the world's traces. Man is an actor - no longer a spectator: an active part of environmental cycles. It is a kind of Earth religion, permeated by an empathy for the biosphere: a biosphere which is part of our physical and psychological identity.

\section{REFERENCES}

[1] Calvino I., Six Memos For the Next Millennium. The Charles Eliot Norton Lectures 1985-86, Vintage International, New York 1993.

[2] MeneghelloL. Deliver us, translated from the Italian by Frederika Randall, Northwestern UP, Evanston 2011.

[3] Meneghello L., La materia di Reading e altri reperti (1997), Rizzoli, Milano 2005.

[4] Meeker J., The Comedy of Survival: Studies in Literary Ecology, Scribner's, New York 1972.

[5] Lotman J., “On the semiosphere”, translated by Wilma Clark, Sign System Studies, 33 (1), 2005. 
[6] Commoner B., the Closing Circle. Nature, Man and Technology, A.A. Knopf, New York 1972.

[7] Zapf H., "Creative Matter and Creative Mind. Cultural Ecology and Cultural Creativity”, in Serenella Iovino, Serpil Oppermann (eds), Material Ecocriticism, Indiana UP, Bloomington 2014, 51-66.

[8] Meneghello L., Le Carte. Volume I: Anni Sessanta, Rizzoli, Milano 2000.

[9] Meneghello L. The Outlaws, translated from the Italian by Raleigh Trevelyan, Michael Joseph, London 1967.

[10] Snyder G., "Reinhabitation”, Earth First!, September 23, 1987, p. 28.

[11] Johnson G.A, The Merleau-Ponty Aesthetics Reader. Philosophy and painting, Northwestern UP, Evanston 1993.

[12] Bateson G., Steps to and Ecology of Mind, Jason Aronson Inc., London 1972.

\section{AUTHORS BIOGRAPHY}

Diego Salvadori holds a $\mathrm{PhD}$ in Comparative Literature and is post-doctoral fellow at LILSI, University of Florence. His current research includes Ecocriticism, Geocriticism, Autobiographical Studies and Digital Humanities. He is in the editorial board of «Lea- Lingue e Letteratured'Oriente e d'Occidente». Among his recent publication are Il giardinoriflesso. L'erbario di Luigi Meneghello (Firenze University Press, 2015); Luigi Meneghello. La biosfera e il racconto (Firenze University Press, 2017). Website: https://unifi.academia.edu/DiegoSalvadori

Citation: Diego Salvadori. "Does Literature belongs to the Biosphere?The Italian Case of Luigi Meneghello". International Journal of Humanities Social Sciences and Education (IJHSSE), vol 5, no. 1, 2018, pp. 117-122. doi: http://dx.doi.org/10.20431/2349-0381.0501018.

Copyright: (C) 2018 Authors. This is an open-access article distributed under the terms of the Creative Commons Attribution License, which permits unrestricted use, distribution, and reproduction in any medium, provided the original author and source are credited. 